\title{
Effect of System Load Factor on Transmission \& Distribution Losses
}

\author{
Sri.S.R.Sadugol \\ ${ }^{1}$ Associate professor, Department of Electrical \& Electronics Engineering BLDEA's CET, Bijapur -586103, \\ Karnataka state, India.
}

\begin{abstract}
Energy losses occur in the process of supplying electricity to consumers due to technical \& commercial losses. The technical losses are due to energy dissipated in the conductors and equipment used for transmission, transformation, sub-transmission and distribution of power. These technical losses are inherent in a system and can be reduced to an optimum level.

The system load factor of the Karnataka State Electricity Board (KEB) during 2009-10 was 70\%, which is considerably low; It is worthwhile to make a study of the effect of system load factor on transmission \& distribution loss reduction \& the consequent increase in profitability of power utilities, with a focus on the Karnataka system. The study shows how the annual savings can be achieved through improvement of load factor.
\end{abstract}

Keywords: $T \& D$ losses, Load factor, Annual Savings, Reduction in $T \& D$ Loss, Load Factor on profitability

\section{Introduction:}

Energy losses occur in the process of supplying electricity to consumers due to technical and commercial losses. The technical losses are due to energy dissipated in the conductors and equipment used for transmission, transformation, sub- transmission and distribution of power. These technical losses are inherent in a system and can be reduced to an optimum level. The losses can be further sub grouped depending upon the stage of power transformation \& transmission system as Transmission Losses $(400 \mathrm{kV} / 220 \mathrm{kV} / 132 \mathrm{kV} / 66 \mathrm{kV})$, as Sub transmission losses $(33 \mathrm{kV} / 11 \mathrm{kV})$ and Distribution losses $(11 \mathrm{kV} / 0.4 \mathrm{kv})$. The commercial losses are also caused by pilferage, defective meters, and errors in meter reading and in estimating unmetered supply of energy. On going through the annual administration report of Karnataka State Electricity Board (KEB) for 2009-12, it is learnt that during this period, the transmission \& distribution loss has come down compared to previous years [1] .This was achieved through the execution of the following improve mental works, commissioning of the details of circuit kilometers of transmission lines and station bay are given in Table-1,Table-2,Table-3, Table-4 respectively, also graph indicating percentage reduction in Transmission Loss of Karnataka State up to 2010-11.

\section{Reasons For High Technical Losses:}

The major reasons for high technical losses in India are:

1. Inadequate investment on transmission and distribution, particularly in sub-transmission \& distribution. While the desired investment ratio between generation and T\&D should be 1:1. Low investment has resulted in overloading of the distribution system without commensurate strengthening and augmentation.

2. Haphazard growths of sub-transmission and distribution system with the short-term objective of extension of power supply to new areas.

3. Large scale rural electrification through long $11 \mathrm{kV}$ and LT lines.

4. Too many stages of transformations.

5. Improper load management.

6. Inadequate reactive compensation.

7. Poor quality of equipment used in agricultural pumping in rural areas, cooler air conditioners and industrial loads in urban areas.

The system load factor of the Karnataka State Electricity Board (KEB) during 2009-10 was 70\%, which is considerably low compared to the other states of India. It is worthwhile to make a study of the effect of system load factor on transmission \& distribution loss reduction \& the consequent increase in profitability of power utilities, with a focus on the Karnataka system. The study shows how the annual savings can be achieved through improvement of load factor. 
Effect of system load factor on transmission \& distribution losses

Table 1: Voltage class wise transmission lines as on

31.03.2011

\begin{tabular}{|c|c|}
\hline $\begin{array}{l}\text { Voltage } \\
\text { Class }\end{array}$ & $\begin{array}{l}\text { Transmission lines } \\
\text { in CKMs }\end{array}$ \\
\hline $400 \mathrm{kV}$ & 1978 \\
\hline $220 \mathrm{kV}$ & 9368 \\
\hline $110 \mathrm{kV}$ & 8752 \\
\hline $66 \mathrm{kV}$ & 9532 \\
\hline TOTAL & 29630 \\
\hline
\end{tabular}

Table-2: No. of Bays as on

31.03.2011

\begin{tabular}{|l|l|}
\hline Type & Numbers \\
\hline Line Bay & 4744 \\
\hline Transformer bay & 1996 \\
\hline PT Bay & 1324 \\
\hline Capacitor Bank Bay & 622 \\
\hline 11 kV Bay & 9008 \\
\hline
\end{tabular}

Table-3.Power Sector at a Glance - As on 31.05.2012

Installed Capacity

\begin{tabular}{|l|l|}
\hline KPC Hydro \& Thermal & $6005.07 \mathrm{MW}$ \\
\hline CGS (Karnataka Share) & $1700 \mathrm{MW}$ \\
\hline NCE,IPPs and Others & $3609.10 \mathrm{MW}$ \\
\hline Total Installed Capacity & $11314.17 \mathrm{MW}$ \\
\hline **No. of Consumers & $1.82 \mathrm{Crs}$. \\
\hline Length of Tr.Lines (length in CKMs) & 39308.797 \\
\hline No. of Stations & 1315 \\
\hline *No. of DTCs & $4,06,637$ \\
\hline *HT Line (length in CKMs) & 226719.464 \\
\hline *LT Lines (Length in KMs) & 474820.661 \\
\hline
\end{tabular}

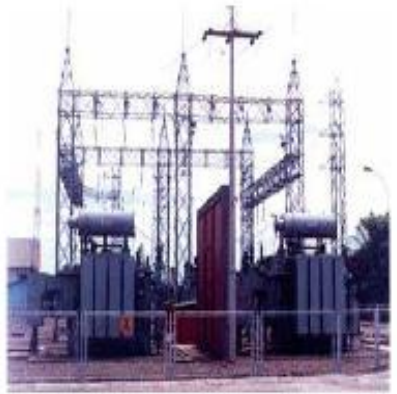

Table-4 . Substations \& Tr Lines - As on 31.05.2012

\begin{tabular}{|l|l|l|}
\hline Voltage Level & No. of Stations & Tr. Line in CKMs \\
\hline $400 \mathrm{kV}$ & 04 & 2291.304 \\
\hline $220 \mathrm{kV}$ & 89 & 9695.745 \\
\hline $110 \mathrm{kV}$ & 330 & 9025.707 \\
\hline $66 \mathrm{kV}$ & 545 & 9703.011 \\
\hline $33 \mathrm{kv}$ & 347 & 8593.03 \\
\hline Total & 1315 & 39308.797 \\
\hline
\end{tabular}

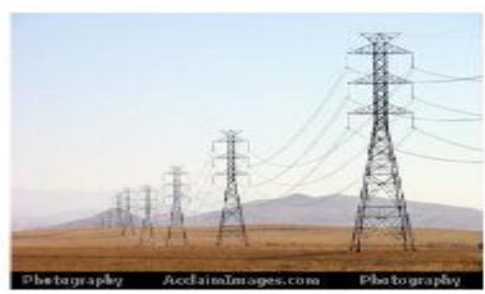

Graph of Transmission Loss in Karnataka State up to 2010-11:

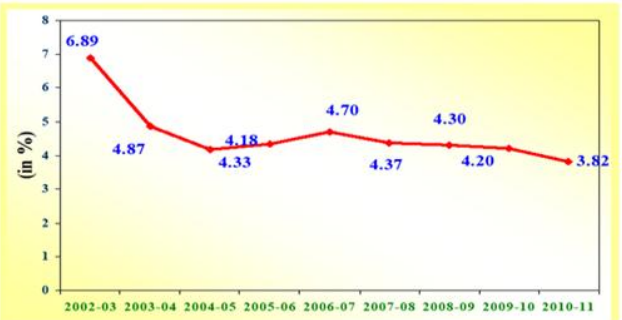

The T\&D losses in India have come down from 32.53 per cent in 2003-04 to 25.39 per cent in 2009-10. Percentage transformation, transmission and distribution losses (including energy unaccounted for). For the Southern Region of India's T\&D Losses is demonstrated by Table no 4.A \& Chart Below.

Table 4. A \& its chart:

\begin{tabular}{|c|c|c|c|c|c|c|c|c|}
\hline Region & STATES/UTS & 2003-04 & 2004-05 & 2005-06 & 2006-07 & 2007-08 & 2008-09 & 2009-10 \# \\
\hline \multirow{6}{*}{ 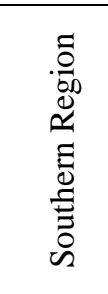 } & $\begin{array}{l}\text { Andhra } \\
\text { Pradesh }\end{array}$ & 27.73 & 23.96 & 20.06 & 18.65 & 22.41 & 19.56 & 18.37 \\
\hline & Karnataka & 23.29 & 27.5 & 29.6 & 29.2 & 25.3 & 23.4 & 21.38 \\
\hline & Kerala & 21.63 & 22.48 & 23.50 & 19.11 & 17.81 & 13.16 & 19.59 \\
\hline & Tamil Nadu & 17.16 & 19.28 & 18.66 & 19.54 & 18.71 & 18.14 & 18.41 \\
\hline & Lakshadweep & 11.85 & 10.20 & 11.19 & 12.87 & 18.05 & 24.87 & 11.59 \\
\hline & Pondicherry & 11.60 & 18.15 & 18.48 & 18.76 & 5.89 & 12.24 & 11.84 \\
\hline & All India & 32.53 & 31.25 & 30.42 & 28.65 & 27.20 & 25.47 & 25.39 \\
\hline
\end{tabular}




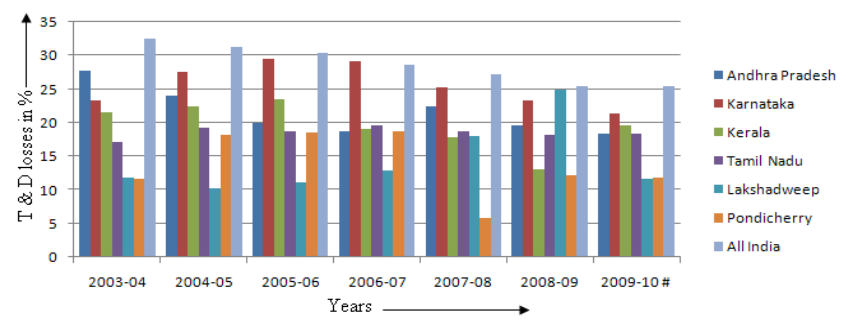

Following is the data acquired for Karnataka State till 2011-12

Table 4. B \& its Chart is the \% of T \& D losses in Karnataka state

\begin{tabular}{|l|l|l|l|l|l|l|l|l|}
\hline Year & $2004-05$ & $2005-06$ & $2006-07$ & $2007-08$ & $2008-09$ & $2009-10$ & $2010-11$ & $2011-12$ \\
\hline $\begin{array}{l}\text { \% of T \& D } \\
\text { losses }\end{array}$ & 27.5 & 29.6 & 29.2 & 25.3 & 23.4 & 21.38 & 20.10 & 19.56 \\
\hline
\end{tabular}

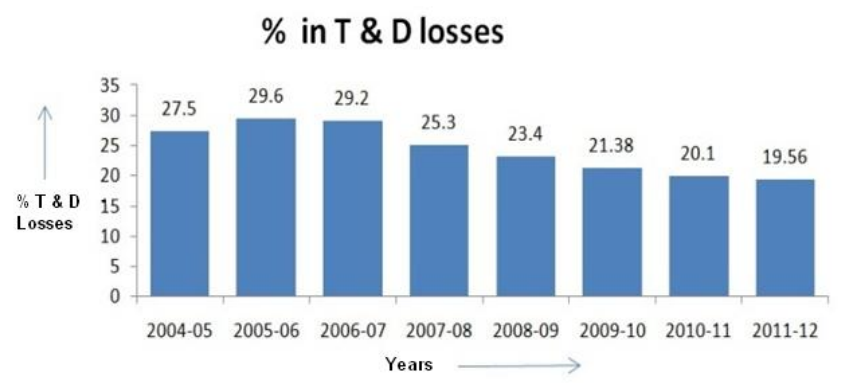

\section{Theoretical Study Of Effect Of System Load Factor On T\&D Losses}

Ideal system loss (Ld): The ideal condition of loading of a system occurs when load factor is $100 \%$. Let us consider a case in which a uniform apparent power of $\mathbf{X}$ unit flows for a time period of T, such that the energy consumption for the period is $\mathbf{Q}$ units.

Load factors $=100 \%$,

Energy consumption $=\mathrm{Q}$ units

Average apparent power $=\mathrm{X}$ units

Current $\mathrm{I}=\mathrm{X} / \mathrm{E}$ (where $\mathrm{E}$ is a constant that depends on voltage etc.)

System loss depends on apparent power and not on active power.

System loss $=\mathrm{D} \times \mathrm{I}^{2} \times \mathrm{T}$ (where D is a constant that depends on the system parameters such as impedance etc.)

$=\mathrm{D} \times(\mathrm{X} / \mathrm{E})^{2} \times \mathrm{T}$

$=\left(\mathrm{D} / \mathrm{E}^{2}\right) \times \mathrm{X}^{2} \mathrm{x} \mathrm{T}$

$=\left(\mathrm{D} / \mathrm{E}^{2}\right) \times(\text { Average apparent power })^{2} \mathrm{x}$ time period

$=\mathrm{K} \times(\text { Average apparent power })^{2} \mathrm{x}$ time period, (where $\mathrm{K}=\mathrm{D} / \mathrm{E}^{2}$ )

This is the minimum possible system loss for any given time period $\&$ the given system parameters. That means, it is the ideal system loss.

Ideal system loss, $\mathbf{L d}=\mathrm{K}$ x (Average apparent power $)^{2} \mathrm{x}$ time period ----- (1).

Also, System loss if apparent maximum demand (MD) is maintained during the time period

$=\mathrm{K} \times(\text { Average apparent maximum demand })^{2} \times$ time period ----- (2)

Note that Ideal system loss, Ld changes when there is any change in the constant $\mathbf{K}$.

The Actual loss can be worked out based on the relation between load factor $\left(G_{L}\right)$ \& loss factor $\left(G_{v}\right)$. In fact, loss factor is the 'load factor of losses'. It is defined as the ratio of actual energy loss during a particular period to the energy loss assuming peak apparent demand throughout the period.

\section{Load Factor \& Loss Factor}

In actual practice, ideal loading never occurs \& the actual system loss will be more than ideal system loss. Losses in series elements are related to the square of the current flow. It is possible to establish a relationship between peak demand on a system \& the average technical losses, through consideration of load factor $\left(\mathrm{G}_{\mathrm{L}}\right)$ \& loss factor $\left(\mathrm{G}_{\mathrm{V}}\right)$.

$\mathrm{G}_{\mathrm{L}}=$ Energy loss over a time period / (Power loss at apparent MD $\mathrm{x}$ the time period)

$\mathrm{G}_{\mathrm{V}}=$ Energy consumed over a time period / (MD $\mathrm{x}$ the time period) 
$\mathrm{G}_{\mathrm{V}}=\left(\mathrm{G}_{\mathrm{L}}\right)^{1.6}$ [Extracted from Electrical Engineering Handbook published by SIEMENS, Section 8.1, Network Parameters, pp 356-357]. [3]

$\mathrm{G}_{\mathrm{L}}=\mathrm{A}_{\mathrm{U}} /$ Pmax x $\mathrm{t}$---- Load factor

$\mathrm{G}_{\mathrm{V}}=\mathrm{A}_{\mathrm{V}} / \mathrm{Vmax} \mathrm{xt}$-----Loss factor

Pmax: maximum transmitted power (peak load) in MW in a certain period.

$t$ : duration of the period in hours,

$\mathrm{A}_{\mathrm{U}}$ : energy transmitted in time $\mathrm{t}$ in $\mathrm{MWh}$,

Vmax : loss power at apparent load power Smax,

Av : energy loss in time t.

No simple curve, which is correct for every case, exists for the relation $G v=f\left(G_{L}\right)$ because of the

effect of power factor and load fluctuation. Ref Figure.1

Graph: Loss factor as $a$ function of load factor (Figure.1)

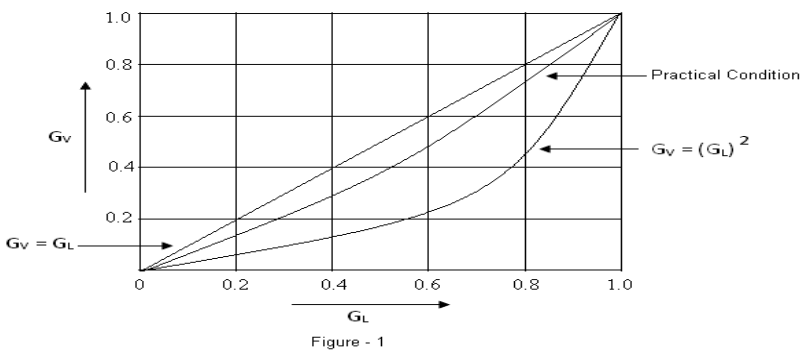

The bandwidth is given by the relation $G v=\left(G_{L}\right)^{1-2}$. The index 1 is valid for a load diagram which only contains the values $\mathrm{P}=\mathrm{P}_{\max } \& \mathrm{P}=0$. A load diagram for index 2 would have the power Pmax during a very short period of time, while a constant load would exist during the rest of the time. The emphasized curve can be used with sufficient accuracy under most practical conditions.

(approximately corresponding to an index of 1.6)].

Now,

$\mathrm{G}_{\mathrm{L}}=$ Energy consumed over a time period / $(\mathrm{MD} \times$ the time period $)$

$=$ Average apparent power / Apparent MD

$\left(\mathrm{G}_{\mathrm{L}}\right)^{2}=(\text { Average apparent power })^{2} /(\text { Apparent MD })^{2}$

$=\left[\mathrm{K} \times(\text { Average apparent power })^{2} \times\right.$ Time period $] /\left[\mathrm{K} \times(\text { Apparent MD })^{2} \times\right.$ Time period $]$

$=$ Ideal loss over a time period (Ld) / (Energy loss if apparent MD is maintained over the time period)

$\mathrm{Gv}=$ Energy loss over a time period / (Power loss at apparent MD $\times$ the time period)

$=$ Actual system loss over a time period / (Energy loss if apparent MD is maintained over the time period)

$\mathrm{Gv} /\left(\mathrm{G}_{\mathrm{L}}\right)^{2}=$ Actual loss over a time period / Ideal loss over the same time period

$=$ Actual loss $/$ Ideal loss $\left(\mathrm{L}_{\mathrm{d}}\right)$

So, Actual loss $=\mathrm{Ld} \times\left[\mathrm{Gv} /\left(\mathrm{G}_{\mathrm{L}}\right)^{2}\right]$

But, we know that $\mathrm{Gv}=\left(\mathrm{G}_{\mathrm{L}}\right)^{1.6}$

So, Actual Loss $=\mathrm{Ld} x\left[\left(\mathrm{G}_{\mathrm{L}}\right)^{1.6} /\left(\mathrm{G}_{\mathrm{L}}\right)^{2}\right]$

Now,

$$
=\operatorname{Ld} \times\left[1 /\left(\mathrm{G}_{\mathrm{L}}\right)^{0.4}\right]
$$

Actual loss $\mathrm{L}_{1}$ at load factor $\mathrm{G}_{\mathrm{L} 1}=\mathrm{Ld} x\left[1 /\left(\mathrm{G}_{\mathrm{L} 1}\right)^{0.4}\right]$

Actual loss $\mathrm{L}_{2}$ at load factor $\mathrm{G}_{\mathrm{L} 2}=\mathrm{Ld} \times\left[1 /\left(\mathrm{G}_{\mathrm{L} 2}\right)^{0.4}\right]$

$\mathrm{L}_{1} / \mathrm{L}_{2}=\left(\mathrm{G}_{\mathrm{L} 2} / \mathrm{G}_{\mathrm{L} 1}\right)^{0.4}$

\section{V. $\quad$ Effect Of Load Factor On Profitability}

From the Annual Report for 2009-12 of Southern Regional Power Committee (under CEA), Bangalore, the statistics with regard to the southern states of India can be obtained, which is presented in Table 5.[2]

From Table $5 \&$ its chart, it is observed that the system load factor of Karnataka state for consecutive years is listed below along with the Southern States of India.

Table 5 \& its Chart.

\begin{tabular}{|l|l|l|l|l|l|l|}
\hline $\begin{array}{l}\text { Annual Load Factor (\%) of } \\
\text { Southern States of India }\end{array}$ & $\begin{array}{l}\text { Andra } \\
\text { Pradesh }\end{array}$ & Karnataka & Kerala & $\begin{array}{l}\text { Tamil } \\
\text { Nadu }\end{array}$ & Pondicherry & $\begin{array}{l}\text { Southern } \\
\text { Region }\end{array}$ \\
\hline $2009-2010$ & 78 & 70 & 65 & 83 & 77 & 81 \\
\hline $2010-2011$ & 74 & 68 & 66 & 82 & 77 & 80 \\
\hline
\end{tabular}




\section{Annual Load Factor of Southern States of India in Percentage}

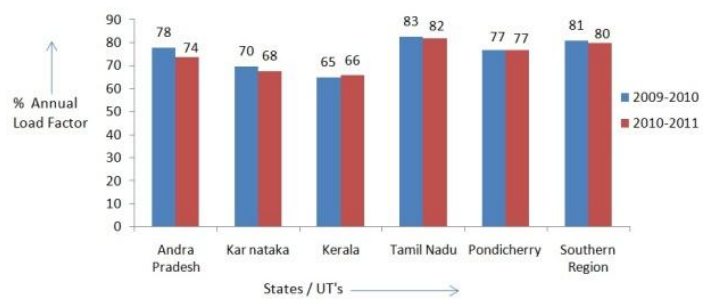

A load factor of $85 \%$ can be taken as the target. From Table 6, the T \& D loss of Karnataka state during 2009-10 was $21.38 \%$ for an annual load factor of $70 \%$. Now, calculate the \% Reduction in T\&D loss, Annual reduction in T\&D Loss in MU \& Annual Savings due to improvement in load factor, if the load factor were improved to $85 \%$. The sample of calculation are shown below. [4]

Table 6

\begin{tabular}{|l|l|l|l|l|}
\hline Years & $\begin{array}{l}\text { \% Annual } \\
\text { Load Factor }\end{array}$ & $\begin{array}{l}\text { \% T \& D } \\
\text { losses }\end{array}$ & $\begin{array}{l}\text { Annual energy } \\
\text { sold in MU }\end{array}$ & $\begin{array}{l}\text { Unit cost of Power } \\
\text { supply ( Paise / Kwh ) }\end{array}$ \\
\hline $2009-2010$ & 70 & 21.38 & 33810 & 408.78 (Rs 4.0878) \\
\hline $2010-2011$ & 68 & 20.10 & 36975 & 462.76 (Rs 4.6276) \\
\hline $2011-2012$ & 71 & 19.56 & 41119 & 459.92 (Rs 4.5992) \\
\hline
\end{tabular}

We know that

$\mathrm{L}_{1} / \mathrm{L}_{2}=\left(\mathrm{GL}_{2} / \mathrm{GL}_{1}\right)^{0.4}$

So, $\mathrm{L} 2=\mathrm{L}_{1} \times\left(\mathrm{GL}_{1} / \mathrm{GL}_{2}\right)^{0.4}$

$\mathrm{T} \& \mathrm{D}$ Loss at $\mathbf{7 0} \%$ load factor, $\mathrm{L}_{1}=0.2138(21.38 \%)$

Suppose the load factor is improved to $85 \%$

$\mathrm{T} \& \mathrm{D}$ Loss at $85 \%$ load factor, $\mathrm{L}_{2}=\mathrm{L}_{1} \mathrm{x}\left(\mathrm{GL}_{1} / \mathrm{GL}_{2}\right)^{0.4}=0.2138 \times(0.7 / 0.85)^{0.4}=0.19782(19.782 \%)$.

Reduction in T\&D Loss $=(21.38-19.782)=1.598 \%$

Annual energy sold in MU during 2009-10 = 33810 MU

Annual reduction in T\&D Loss $=33810 \times(1.598 / 100)=540.2838 \mathrm{MU}$.

Per unit cost of energy $=$ Rs 4.0878

Annual Savings due to improvement in load factor in Rs. $=540.2838 \times 10^{5} \times 4.0878$

$$
=\text { Rs } 220,85,72,118
$$

In Crores. $=\mathbf{2 2 0 . 8 5 7 2 1 1 8}$.

From Table 7, it is observed that as the system load factor increases, \% Reduction in T \& D Loss decreases \& vica-versa. It also specifies the Annual Savings due to improvement in load factor in crores of Karnataka state for consecutive years is listed below.

Table $7 \&$ its Chart. Assuming Load factor improved to 85\%

\begin{tabular}{|l|l|l|l|l|l|l|l|}
\hline Year & $\begin{array}{l}\text { \%Existin } \\
\text { g Load } \\
\text { factor }\end{array}$ & $\begin{array}{l}\text { \%T \& D } \\
\text { Loss }\end{array}$ & $\begin{array}{l}\text { \% Reduction } \\
\text { in T \& D } \\
\text { Loss }\end{array}$ & $\begin{array}{l}\text { Annual } \\
\text { energy } \\
\text { sold in } \\
\text { MU }\end{array}$ & $\begin{array}{l}\text { Annual } \\
\text { reductio } \\
\text { n in T \& } \\
\text { D Loss } \\
\text { MU }\end{array}$ & $\begin{array}{l}\text { Per } \\
\text { Unit } \\
\text { cost of } \\
\text { Energy } \\
\text { in Rs }\end{array}$ & $\begin{array}{l}\text { Annual Savings } \\
\text { due to } \\
\text { improvement in } \\
\text { load factor in } \\
\text { crores }\end{array}$ \\
\hline $2009-10$ & 70 & 21.38 & 1.598 & 33810 & $\begin{array}{l}540.283 \\
8\end{array}$ & 4.0878 & 220.8572118 \\
\hline $2010-11$ & 68 & 20.10 & 1.72 & 36975 & 635.97 & 4.6276 & 294.3014772 \\
\hline $2011-12$ & 71 & 19.56 & 1.3586 & 41119 & 558.645 & 4.5992 & 256.9323477 \\
\hline
\end{tabular}




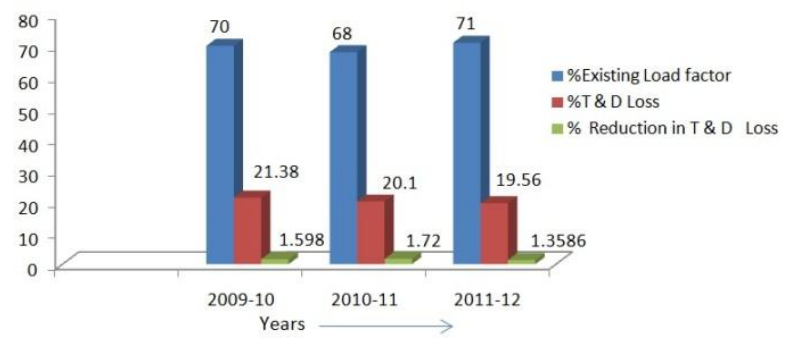

\section{Additional Savings Due to improvement in Load Factor}

Capacity enhancement of the system (generation, transmission and distribution) is usually necessitated to meet the evening peak demand. If load factor is improved, evening peak will be reduced and consequently there will be savings due to the reduction in capital investment. Load factor can be improved only by flattening of the load curve. It can be done only by limiting the evening peak and by creating additional demand during off-peak periods.

The frequency will usually be low during the evening peak. Under the availability - based tariff (ABT) regime, there will be a monetary benefit if there is any reduction in demand during the low-frequency period.

\section{Conclusion:}

1) Action plan for achieving loss reduction by improvement of system load factor.

Load factor can be improved only by flattening of the load curve. It can be done only by limiting the evening peak and by creating additional demand during off-peak periods.

2) According to the methodologies, the implementation of EE (Energy Efficient ) measures for T\&D loss reduction can include:

a) Up-grading the voltage on a transmission/distribution system.

b) Replacing existing transformers with more efficient transformers (e.g., replacement of a silicon steel core transformer with an amorphous metal transformer).

c) Increasing the amount of pipe insulation in a district heating system. The technologies or measures may be applied to an existing transmission or distribution systems or be part of an expansion of a transmission /distribution system.

d) Assuming a net reduction of $15 \%$ in $T \& D$ losses can be achievable by implementing energy efficiency measure in the distribution network in near future up to 2020--2021.

3) The present $\mathrm{CO} 2$ emission level of the regional gird, is estimated by Central Electivity Authority (CEA). Therefore, the Reduction in T\&D losses provides an opportunity for net carbon emission reduction.

\section{REFERENCES:}

[1] KEB, Annual Administration Report 2009-2012 of Karnataka state Electricity Board, Bangalore, India.

[2] SRPC, Annual Report 2009-2012 of Southern Region Power Committee, Bangalore, India. (under CEA). www.srpc.kar.nic.in.

[3] SIEMENS (1981) Electricity Engineering Handbook, New Delhi, India: New Age International Private Limited.

[4] Economic Survey of Karnataka state, 2009-2012. 